\title{
EVALUASI PENUGASAN CLINICAL REASONING DAN REFLEKSI MAHASISWA DI SKILLS LAB FK UGM
}

\author{
Widyandana \\ Bagian Pendidikan Kedokteran, Universitas Gadjah Mada \\ Yogyakarta
}

\section{ABSTRACT}

Background: Teaching clinical reasoning and reflection skills in skills laboratory are usually neglected, therefore Skills Lab of FM GMU initiate to teach those skills for undegraduate students.

Aim: This study aimed to evaluate student's assignment of clinical reasoning and reflection skills and explore how to improve it.

Methods: An experimental study by giving student assignments to make an essay about particular disease based on SKDI level 4 that written on a medical record and reflection form format. All $4^{\text {th }}$-year medical students of FM GMU ( $\left.n=186\right)$ and skills lab instructors ( $n=5$ ) were involved. Assignments were assessed (by the instructors) using instrument by Driessen (2008), and analyzed by correlating those scores with students' OSCE score and GPA using Pearson Correlation test. Qualitative data collected by deep interview with assessors and analyzed using Inductive Content Analysis by 2 coders.

Results and Discussion: There were no significant correlation between assignment score with OSCE score and GPA. However, there were significant correlations $(p<0.05)$ between score of clinical reasoning with reflection skills, and OSCE score with GPA. Assessors conclude that assignment has been good enough to stimulate clinical reasoning and reflection skills, but still had weaknesses e.g. incompatibility of assignment's format to assessment's checklist, unclear instructions, and no example that students submitted in various format.

Conclusion: The assignment has been succesfully conducted in Skills laboratory FM GMU, however it needs some improvement, such as giving detail instructions, examples, and matching it with assessment instrument.

Keywords: Clinical reasoning, reflection, OSCE, GPA

\section{ABSTRAK}

Latar Belakang: Pembelajaran keterampilan clinical reasoning dan refleksi di skills lab masih sering dilupakan, maka Skills Lab FK UGM berinisiatif untuk memberikan keterampilan tersebut bagi mahasiswa S1 kedokteran. Penelitian ini bertujuan untuk mengevaluasi penugasan clinical reasoning dan refleksi mahasiswa, serta mengetahui cara memperbaikinya.

Metode: Penelitian eksperimental dengan pilot program memberikan penugasan membuat essay penyakit berdasar SKDI tingkat kompetensi 4 yang dikerjakan dalam format rekam medis dan lembar refleksi. Penelitian melibatkan seluruh mahasiswa kedokteran tahun ke-4 FK UGM ( $n=186)$ dan instruktur skills lab sebagai penilai ( $n=5)$. Penugasan dinilai menggunakan instrument oleh Driessen (2008) dan dianalisis dengan uji Pearson Correlation untuk mengkorelasikan nilai penugasan dengan nilai OSCE dan IPK. Data kualitatif diperoleh dengan wawancara pada instruktur dan dianalisis menggunakan Inductive Content Analysis oleh 2 pengkode.

Hasil dan Pembahasan: Tidak terdapat korelasi signifikan antara nilai penugasan dengan nilai OSCE dan IPK.

Korespondensi: widyandana@yahoo.com 
Namun, terdapat korelasi signifikan $(\mathrm{p}<0,05)$ antara nilai refleksi dengan clinical resoning, serta nilai OSCE dengan IPK. Penilai berpendapat bahwa penugasan ini sudah cukup baik untuk menstimulasi clinical reasoning dan refleksi mahasiswa meski masih terdapat kekurangan, antara lain kurang sesuainya format penugasan dengan checklist penilaian, ketidakjelasan instruksi, dan tidak adanya contoh sehingga mahasiswa mengumpulkan dalam berbagai format .

Kesimpulan: Penugasan clinical reasoning dan refleksi berhasil dilaksanakan di Skills Lab FK UGM tetapi masih memerlukan perbaikan, antara lain ketidaksesuaian format penugasan dengan checklist penilaian, ketidakjelasan instruksi, dan tidak adanya contoh sehingga mahasiswa mengumpulkan dalam berbagai format .

Kata Kunci: clinical reasoning, refleksi, OSCE, IPK

\section{PENDAHULUAN}

Skills lab berperan penting untuk melatih keterampilan medis mahasiswa kedokteran dalam memenuhi standar kompetensi selama jenjang S1. ${ }^{1,2}$ Pembelajaran keterampilan medis di skills lab bertujuan untuk dapat menyiapkan mahasiswa kedokteran memasuki pendidikan profesi. Hal ini sesuai dengan penelitian terbaru yang menunjukkan bahwa belajar keterampilan medis memang terbukti mampu meningkatkan motivasi belajar, tingkat kepercayaan diri, dan menyiapkan mahasiswa untuk memasuki pendidikan profesi. ${ }^{2-4}$ Selanjutnya, keuntungan lain dari belajar keterampilan medis di skills lab ${ }^{3}$ adalah latihan dapat diajarkan secara aman, sederhana, dan setiap situasi dapat dikontrol. Suatu keterampilan medis dapat dilakukan berkali-kali dengan aman, tanpa takut mencederai pasien. Di dalam laboratorium, kesalahan dapat ditolerir, dan mahasiswa dapat diberikan feedbacksecara langsung oleh instruktur tanpa harus mengganggu pelayanan terhadap pasien.

Dalam sebuah sistematik review mengenai efektifitas pendidikan keterampilan medis terhadap tingkat keterampilan mahasiswa juga menunjukkan bahwa mahasiswa yang dilatih di skills lab secara signifikan lebih terampil dibanding mahasiswa yang tidak dilatih di skills lab. ${ }^{5}$ Menyadari akan kepentingan keterampilan medis di skills lab tersebut, maka pelatihan keterampilan medis sebaiknya direncanakan dengan baik agar tercipta program yang ideal bagi mahasiswa kedokteran. Hal ini merujuk pada rekomendasi General Medical Council (GMC) tahun 2003, dalam Tomorrow's Doctor ${ }^{11}$ yang menunjukkan bahwa selama proses belajar, kurikulum kedokteran harus dapat memberikan pengetahuan yang essensial, keterampilan dan perilaku yang baik kepada mahasiswa kedokteran sebelum mereka lulus. Pelatihan keterampilan medis sebaiknya dimulai sejak dini, diawali dengan yang paling sederhana berlanjut kesemakin kompleks, diintegrasikan dengan tema blok dalam kurikulum sehingga membuat mahasiswa tertarik dan terfokus dalam belajar. ${ }^{12}$ Teori dan keterampilan yang diajarkan juga harus sesuai dengan realitas (contextual), sehingga mudah dimengerti oleh mahasiswa.

Selama ini, pelaksanaan skills lab dilakukan dengan memberikan pelatihan keterampilan medis secara terstruktur dan terencana dengan baik, dengan menggunakan berbagai metode, yaitu berlatih dengan manikin, dengan teman, pasien simulasi, maupun berlatih langsung di masyarakat. ${ }^{6}$ Sebagai salah satu contoh, Skills Lab FK UGM yang sudah merintis pendidikan keterampilan medis di skills lab sejak tahun 1992 memberikan pendidikan keterampilan medis mereka secara longitudinal dalam seluruh tahapan kurikulum pendidikan S1 kedokteran. Masing-masing topik di skills lab diberikan dalam beberapa tahapan. Tahap pertama, mahasiswa diajarkan keterampilan klinis oleh seorang intruktur yang ahli/ telah terlatih dan menguasai keterampilan medis tertentu. Dalam latihan ini mahasiswa dapat berlatih dengan manikin, roleplay dengan teman maupun pasien simulasi, dan terjun langsung ke masyarakat. Masing-masing topik diberikan dengan metode yang berbeda-beda sesuai dengan karakteristik topik yang diajarkan. Setelah berlatih dengan instruktur, kemudian mahasiswa diberi 
kesempatan untuk berlatih secara mandiri untuk dapat menguasai suatu topik keterampilan tersebut. ${ }^{13}$

Namun, mahasiswa S1 kedokteran masih sering mengalami kesulitan untuk mengaplikasikan teori yang sudah didapatkan selama pendidikan S1 kedokteran ke dalam pendidikan profesi. ${ }^{14}$ Dalam pendidikan profesi mahasiswa akan berhadapan langsung dengan pasien yang sebenarnya dalam situasi klinis. ${ }^{2}$ Mereka sering kali tidak siap melakukan suatu prosedur medis yang semula berlatih dengan manikin di skills lab kemudian diminta menerapkannya ke pasien yang sebenarnya. ${ }^{4,15}$ Kecemasan juga muncul ketika mahasiswa pertama kali berhadapan dengan pasien di rumah sakit karena mereka takut melakukan kesalahan medis yang mungkin akan membahayakan pasien. ${ }^{15,16}$ Selain itu, permasalahan tersebut juga terkait dengan masalah lemahnya kemampuan clinical reasoning, sosialisasi, beban kerja, dan keberbedaan antara teori dengan praktik.

Kesiapan mahasiswa FK UGM untuk memasuki pendidikan profesi/koasisten juga pernah diteliti oleh Yuwono $\mathrm{dkk}^{17}$ yang menunjukkan bahwa kesiapan mahasiswa masih rendah. Dalam penelitian tersebut rendahnya kesiapan meliputi pengetahuan medis atau clinical reasoning, keterampilan komunikasi, pemeriksaan fisik dan prosedur medis. Kesempatan untuk mahasiswa berlatih, refleksi, dan stimulasi untuk meningkatkan kemampuan clinical reasoning mahasiswa kemungkinan masih kurang atau belum tepat, sehingga membuat mereka tidak mampu mencapai kompetensi yang dibutuhkan ketika memasuki pendidikan profesi.

Menanggapi permasalahan di atas, salah satu solusi yang dapat dilakukan adalah dengan melatih kemampuan clinical reasoning dan refleksi pada mahasiswa dengan penugasan yang tepat. Mengingat akan pentingnya kemampuan clinical reasoning dan refleksi bagi mahasiswa kedokteran memberikan peran sentral dalam pencapaian kompetensi keterampilan medis. ${ }^{6,7}$ Keterampilan clinical reasoning penting agar mahasiswa dapat melakukan penalaran klinis yang logis dalam menentukan tindakan medis. Tanpa adanya kemampuan clinical reasoning yang baik, mahasiswa kedokteran sangat berisiko untuk dapat melakukan kesalahan dalam manajemen pasien.

Selanjutnya refleksi dalam setiap aktifitas pembelajaran di kampus diperlukan mahasiswa untuk dapat mempelajari clinical reasoning dengan baik. Hubungan yang kuat dalam tingkat keaktifan refleksi dengan kemampuan clinical reasoning menunjukkan bahwa dua hal tersebut saling terkait dan tidak dapat dipisahkan dalam pencapaian kompetensi mahasiswa sebelum memasuki pendidikan profesi. ${ }^{8} \mathrm{Hal}$ ini sejalan dengan banyak teori proses pembelajaran yang menunjukkan bahwa semakin mahasiswa aktif berlatih dan melakukan refleksi, maka proses pemahaman terhadap suatu prosedur medis atau teori akan lebih baik dibandingkan mahasiswa yang cenderung pasif. 9

Secara umum kesempatan mahasiswa untuk berlatih keterampilan medis lebih awal di skills lab, dan dengan metode pembelajaran yang tepat, diharapkan dapat meningkatkan kemampuan clinical reasoning dan refleksi mahasiswa sebagai bekal memasuki pendidikan profesi. ${ }^{9} 10$ Oleh karena itu, penelitian ini bertujuan untuk mengevaluasi pilot program penugasan clinical reasoning dan refleksi dari Skills Lab FK UGM dengan melihat korelasi penugasan tersebut dengan nilai OSCE dan IPK, serta dengan mengeskplorasi pendapat dari penilai untuk meningkatkan kualitas program tersebut.

\section{METODE}

Setelah mendapatkan surat ethical clearance, penelitian ini baru mulai dilaksanakan. Penelitian eksperimental dengan menyelenggarakan pilot program dengan memberikan penugasan clinical reasoning dan refleksi pada mahasiswa. Penugasan ini melibatkan seluruh maha-siswa tahun ke-4 kelas reguler angkatan 2007 FK UGM $(n=186)$ dan instruktur Skills Lab FK UGM sebagai penilai penugasan $(n=5)$. Semua mahasiswa tahun ke-4 program regular, angkatan 2007 FK UGM dengan kurikulum KBK yang telah mendapatkan pembelajaran di Skills Lab dan OSCE Komprehensif diikutsertakan dalam penelitian ini. Sedangkan untuk lima instruktur skills lab yang menilai kemampuan clinical reasoning dan refleksi mahasiswa dipilih secara acak dan diberikan pelatihan terlebih dahulu untuk menyamakan persepsi mengenai metode penilaian. ${ }^{18}$

Masing-masing mahasiswa diberikan tugas untuk membuat essay tentang satu penyakit di dalam Standar Kompetensi Dokter Indonesia (SKDI) dengan tingkat kompetensi 4. Setelah membuat rangkuman atau essay, 
mahasiswa diminta untuk mensimulasikan penerapannya dalam bentuk satu set rekam medis dari RS DR. Sardjito. Selanjutnya mahasiswa juga diminta menuliskan refleksi mengenai pengerjaan tugas.

Evaluasi penugasan dilakukan dengan mengkorelasikan nilai penugasan dengan nilai OSCE dan IPK serta menggali pendapat penilai penugasan. Instrumen untuk menilai kemampuan clinical reasoning adalah cek list yang sudah dibakukan oleh Skills Lab FK UGM berdasarkan instrument Driessen (2008). ${ }^{19}$ Nilai clinical reasoning dan refleksi dianalisis secara desriptif kuantitatif, kemudian dikorelasikan dengan nilai OSCE dan nilai IPK mahasiswa menggunakan uji korelasi pearson. ${ }^{20}$ Selanjutnya, analisis kualitatif hasil wawancara menggunakan inductive content analysis oleh 2 pengkode, yaitu peneliti utama dan satu instruktur skills lab. ${ }^{21}$

\section{HASIL DAN PEMBAHASAN}

\section{HASIL}

Responden penelitian ini adalah 74 orang, dari 186 mahasiswa FK UGM tahun ke-4 program reguler kurikulum KBK angkatan 2007 (respon rate=40\%) yang bersedia mengumpulkan penugasan untuk log book clinical reasoning dan refleksi, mahasiswa yang lain tidak mau terlibat dengan alasan kesibukan dan tidak mampu mengupulkan tugas pada waktu yang ditentukan. Kemudian, setelah diteliti dari 74 hasil penugasan tersebut, sebanyak 35 penugasan terisi lengkap (47, 29\%), sedangkan sisanya tidak lengkap sehingga beberapa poin penilaian tidak dapat dinilai dengan sempurna oleh dua orang penilai yang bertugas.

Hasil korelasi nilai penugasan clinical reasoning dan refleksi dengan nilai OSCE dan IPK

Hasil penelitian ini menunjukkan bahwa tidak ada korelasi signifikan antara hasil penilaian penugasan clinical reasoning dan refleksi dengan nilai OSCE dan IPK. Akan tetapi, terdapat korelasi signifikan antara nilai OSCE dengan IPK $(p=0,00)$, dan nilai clinical reasoning dengan refleksi $(p=0,00)$. Hasil korelasi selengkapnya dapat dilihat dalam Tabel 1 .

Tabel 1. Korelasi antara nilai IPK, OSCE, Refleksi dan Clinical reasoning

\begin{tabular}{|c|c|c|c|c|c|}
\hline & & IPK & OSCE & CR & REFL \\
\hline \multirow[t]{3}{*}{ IPK } & $\begin{array}{l}\text { Pearson } \\
\text { Correlation }\end{array}$ & 1 & $511\left(^{* *}\right)$ & 0,081 & 0,171 \\
\hline & Sig. (2-tailcd) & & 0,000 & 0,495 & 0,151 \\
\hline & $\mathrm{N}$ & 73 & 73 & 73 & 72 \\
\hline \multirow[t]{3}{*}{ OSCE } & $\begin{array}{l}\text { Pearson } \\
\text { Correlation }\end{array}$ & $0,511\left(^{* *}\right)$ & 1 & $-0,001$ & 0,050 \\
\hline & Sig. (2-tailed) & 0,000 & & 0,996 & 0,675 \\
\hline & $\mathrm{N}$ & 73 & 73 & 73 & 72 \\
\hline \multirow[t]{3}{*}{$\mathrm{CR}$} & $\begin{array}{l}\text { Pearson } \\
\text { Correlation }\end{array}$ & 0,081 & $-0,001$ & 1 & $0,530(*)$ \\
\hline & Sig. (2 tailed) & 0,495 & 0,996 & & 0,000 \\
\hline & $\mathrm{N}$ & 73 & 73 & 73 & 72 \\
\hline \multirow[t]{3}{*}{ REFL } & $\begin{array}{l}\text { Pearson } \\
\text { Correlation }\end{array}$ & 0,171 & 0,050 & $0,530(* *)$ & 1 \\
\hline & Sig. (2-tailed) & 0,151 & 0,675 & 0,000 & \\
\hline & $\mathrm{N}$ & 72 & 72 & 72 & 72 \\
\hline
\end{tabular}

** Correlation is significant at the 0.01 level (2-tailed). 


\section{Hasil Wawancara Penilai Penugasan (instruktur skills lab)}

Pada penelitian ini, penilai diminta memberikan feedback terkait dengan penugasan log book clinical reasoning dan refleksi. Dari hasil tersebut didapatkan bahwa instrument penugasan clinical reasoning dan refleksi sudah cukup baik, meski masih perlu perbaikan terkait proses penilaian. Perbaikan terutama terkait dengan adanya beberapa ketidaksesuaian format penugasan dengan check list penilaian. Instruktur berpendapat bahwa antara instrumen penilaian dan hasil penugasan dari mahasiswa masih kurang sesuai sehingga banyak poin yang tidak dapat dinilai sempurna dalam penilaian ini, terutama pada lembar refleksi.

“ ... untuk checklist refleksi apa yang ada di checklist dan bahan yang dinilai tidak sesuai, jadi hasil penilaian tidak terlalu mewakili hasil refleksi sebenarnya...”P1

Instruktur juga mengungkapkan bahwa untuk rentang penilaian check list, definisi masingmasing skor kurang dapat dimengerti karena tidak adanya penjelasan pada setiap rentang penilaian.

“...rentang penilaian diperpendek saja, dan keterangan penilaian harap lebih didetailkan lagi...” P1

Terakhir, instruktur mengungkapkan petunjuk pengerjaan tugas clinical reasoning dan refleksi dinilai kurang detail, sehingga ada banyak variasi laporan yang dibuat oleh mahasiswa.

“...format penugasan antar mahasiswa juga berbeda, ada yang memang bagus sekali ada juga yang kurang bagus, bahkan tidak lengkap... instruksi penugasan ke mahasiswa harap diperjelas lagi, disamakan formatnya antar mahasiswa..."P2

\section{PEMBAHASAN}

Dari hasil penelitian ini diketahui bahwa tidak terdapat korelasi signifikan antara nilai penugasan clinical reasoning dan refleksi dengan nilai OSCE dan IPK. Namun, terdapat korelasi signifikan $(p<0,05)$ antara nilai clinical reasoning dengan refleksi dan nilai OSCE dengan IPK. Penilai berpendapat bahwa penugasan sudah cukup baik untuk menstimulasi clinical reasoning dan refleksi mahasiswa meski masih terdapat kekurangan pada instrumen penugasan, misal beberapa ketidaksesuaian format penugasan dengan check list penilaian.

Seperti yang telah disebutkan sebelumnya, penugasan ini dilakukan untuk memberikan pembelajaran clinical reasoning dan refleksi bagi mahasiswa kedokteran. Pembelajaran ini perlu karena dalam konteks praktik medis, dibutuhkan seorang profesi kesehatan yang memiliki pengetahuan yang kaya dan keterampilan klinis yang terlatih. ${ }^{28-29}$ Status, definisi dan operasi dari suatu profesi sangat bergantung pada dasar pengetahuan mengingat pengetahuan adalah penting untuk alasan professional dan pembuatan keputusan. ${ }^{30}$

Clinical reasoning merupakan inti dari praktik sebagai seorang dokter. ${ }^{22}$ Clinical reasoning dibutuhkan terutama untuk membantu pengambilan keputusan atas suatu permasalahan medis. Clinical reasoning berkaitan erat dengan pengetahuan dan kemampuan mahasiswa saat menjadi dokter nantinya dan merupakan hal yang tidak dapat saling dipisahkan. ${ }^{24-26}$ Proses untuk melakukan clinical reasoning tersebut membutuhkan suatu evaluasi mandiri. ${ }^{23}$ yang tidak akan dapat dilakukan tanpa adanya pengembangan dan pembaharuan secara berkala akan pengetahuan dasar yang dimiliki seorang dokter. ${ }^{22}$

Sementara itu, refleksi adalah proses yang dapat menciptakan pemahaman lebih baik. Sehingga untuk rencana aksi ke depan, jika hal yang sama terjadi maka dapat tertangani dengan baik. Refleksi juga disebut sebagai aspek essensial untuk pembelajaran seumur hidup. ${ }^{27}$ Dalam proses pembelajaran kedokteran, semakin mahasiswa aktif berlatih dan melakukan refleksi, maka proses pemahaman terhadap suatu prosedur medis atau suatu teori akan lebih baik dibandingkan dengan mahasiswa yang cenderung pasif. ${ }^{9}$

Oleh karena itu, dengan adanya kemampuan clinical reasoning dan refleksi yang baik, maka diharapkan memberikan hasil yang baik bagi hasil studi mahasiswa yang diwujudkan dengan nilai OSCE dan nilai IPK. Nilai penugasan clinical reasoning dapat menggambarkan kemampuan clinical reasoning mahasiswa, demikian halnya nilai penugasan refleksi terhadap kemampuan refleksi. OSCE komprehensif merupakan ujian yang merepresentasikan keadaan mahasiswa pada saat praktik 
menjadi dokter nanti. Sedangkan nilai IPK dapat digunakan untuk mengetahui pengetahuan yang dimiliki oleh mahasiswa.

Meski demikian pada penelitian ini didapatkan hasil korelasi yang tidak signifikan antara nilai penugasan clinical reasoning dan refleksi dengan nilai OSCE dan IPK. Hal ini kemungkinan dapat disebabkan oleh adanya beberapa kekurangan pada instrumen penugasan. Misal, adanya ketidaksesuaian format penugasan dengan check list penilaian, ketidakjelasan instruksi, dan tidak adanya contoh sehingga mahasiswa mengumpulkan dalam berbagai format. Hal lain dari sisi responden adalah ketidaksiapan mahasiswa dalam mengerjakan tugas dengan sungguh-sungguh, seperti yang diutarakan oleh penilai.

Penilai menunjukkan bahwa ketidaksesuaian format penugasan dengan check list penilaian terdapat hanya dalam beberapa item, tidak secara keseluruhan. Ketidaksesuaian tersebut antara lain terdapat pada poin penilaian desain sampul dan penjilidan, poin penilaian ketepatan dan kesesuaian penulisan tatalaksana nonfarmakologis dengan diagnosis, poin penilaian hasil dokumentasi, dan poin penilaian penulisan referensi. Poin penilaian untuk desain sampul dan penjilidan kurang sesuai karena penugasan ini dikumpulkan per kelompok sehingga tidak ada desain secara individu. Sedangkan pada poin penilaian hasil dokumentasi , ketidaksesuaian terjadi karena tidak semua mahasiswa mencantumkan hasil dokumentasi berupa hasil laboratorium, gambar, ataupun video.

Selanjutnya hasil penilaian poin-poin lain dalam instrumen dirasa kurang dapat merepresentasikan kemampuan refleksi. Dalam instrumen disebutkan tentang perasaan saat melakukan kegiatan, kekurangan dan kelebihan dari kegiatan, hal yang bisa dipelajari dan rencana aktual yang dilakukan jika terjadi kembali. Namun dalam penugasan tidak tertera spesifik tentang poin-poin di atas sehingga hanya mahasiswa yang mengerjakan dengan lengkap yang dapat dinilai.

Selain hal-hal tersebut, hasil yang tidak signifikan pada hasil penelitian ini kemungkinan disebabkan oleh penugasan yang diberikan kepada mahasiswa masih terbilang baru, sehingga mahasiswa mengalami kesulitan dalam membuat tugas. Hal ini dapat dilihat dari penugasan yang dilakukan mahasiswa, dimana mereka masih belum mengerti essensi dari penugasan tersebut sehingga masih banyak yang belum menuliskan clinical reasoning-nya. Temuan lain adalah rekam medis yang menjadi salah satu bahan penilaian, masih ditemukan dalam keadaan kosong, sehingga banyak rekam medis yang tidak bisa dinilai atau mendapatkan nilai yang tidak begitu bagus.

Salah satu feedback yang diberikan oleh instruktur penilai adalah instrumen penilaian yang berupa check list memiliki rentang yang terlalu lebar dan tidak disertai dengan keterangan yang mendetail mengenai bagaimana cara memberikan penilaian pada kotak keterangan. Hal tersebut membuat instruktur penilai kebingungan dalam melakukan penilaian.

Menyadari akan kelemahan penyusunan instrumen dan penugasan untuk penelitian ini, maka untuk penelitian selanjutnya perlu dilakukan persiapan yang lebih matang, terutama dalam validasi dan review dari penugasan yang diberikan ke mahasiswa, instrumen penilaian, serta instruktur penilainya. Penugasan yang diberikan sebaiknya disusun lebih terintegrasi, sehingga dapat meningkatkan keterampilan klinis, motivasi belajar, tingkat kepercayaan diri, dan menyiapkan mahasiswa untuk memasuki pendidikan profesi. Penugasan clinical reasoning dan refleksi ini sebaiknya tidak diberikan satu kali saja, namun ada baiknya diberikan secara terus menerus dan berulang-ulang, dimulai sejak dini, diawali dengan yang paling ringan berlanjut ke semakin kompleks, diintergasikan dengan tema blok dalam kurikulum sehingga membuat mahasiswa tertarik dan terfokus dalam belajar. ${ }^{12}$ Teori dan keterampilan yang diajarkan juga harus sesuai dengan realitas (contextual), sehingga mudah dimengerti oleh mahasiswa sehingga mempermudah dalam pencapaian kompetensi mahasiswa. ${ }^{6,7}$

Kekurangan dalam penelitian ini adalah keterbatsan waktu dan responden penelitian. Jika penugasan clinical reasoning dan refleksi diberikan pada waktu yang lebih lama, dan kepada jumlah responden yang lebih banyak kemungkinan akan dapat memberikan hasil yang berbeda. Selanjutnya, besar harapan tim penulis dari evaluasi pilot program ini dapat menjadi dasar inovasi pendidikan dikemudian hari, serta dapat dijadikan 
bahan pertimbangan bagi institusi diluar Skills Lab FK UGM jika ingin mengembangkan latihan clinical reasoning dan refleksi mahasiswa yang ideal. Dengan mengambil pelajaran dari pilot program ini, diharapakan kualitas pendidikan keterampilan medis untuk S1 lebih baik lagi, khususnya dalam hal clinical reasoning skills dan kemampuan refleksi.

\section{KESIMPULAN}

Dari hasil penilaian penugasan clinical reasoning dan refleksi mahasiswa diketahui tidak ada korelasi signifikan antara nilai penugasan dengan nilai IPK dan OSCE komprehensif. Namun ada korelasi yang kuat antara nilai refleksi denga clinical reasoning mahasiswa, dan nilai IPK dengan nilai OSCE komprehensif. Instruktur skills lab sebagai penilai penugasan berpendapat bahwa penugasan clinical reasoning dan refleksi oleh skills lab FK UGM sudah cukup baik untuk dalam menstimulasi clinical reasoning dan refleksi mahasiswa meski masih terdapat kekurangan yang membutuhkan perbaikan dikemudian hari.

\section{SARAN}

Penelitian selanjutnya dirancang lebih baik dengan persiapan yang lebih matang. Persiapan tersebut terutama diperlukan dalam perbaikan instrumen penugasan. Lebih spesifik perbaikan instrumen penugasan meliputi kesesuaian format penugasan dengan check list penilaian, kejelasan instruksi penugasan, dan adanya contoh sehingga mahasiswa mengumpulkan dalam format yang sama.

\section{DAFTAR PUSTAKA}

1. Liddell MJ, Davidson SK, Taub H, Whitecross LE. Evaluation on procedural skills training in an undergraduate curriculum. Med Educ. 2002;36:1035-41.

2. Nielsen DG, Moercke AM, Hansen GW, Eika B. Skills training in laboratory and clerkship: connections, similarities, and differences. Med Educ Online [Internet]. 2003 [cited 2009 Apr 10];8:12. Available from http://www.med-ed-online.org.

3. Van Dalen J, Flippo-Berger JF. Skills lab: centre for training of skills. Maastricht: Maastricht University Press, 1999.
4. Smith B. From simulation to reality - breaking down the barriers. Clin Teach. 2006;3:112-7.

5. Lynagh M, Burton R, Fisher RS. A systematic review of medical skills laboratory training: where to from here? Med Educ. 2007; 41:879-87.

6. Leddingham IM, Harden RM. Twelve tips for setting up clinical skills training facility. Med Teach. 1998; 20(6): 503-7.

7. Norman G. Research in clinical reasoning: past history and current trends. Med Educ. 2005; 39: 418-27.

8. Windish DM. Teaching medical students clinical reasoning skills. Acad Med. 2000; 75(1):90.

9. Custers EJFM, Regehr G, Mcculloch W, Peniston C, Reznick R. The effects of modelling on learning a simple surgical procedure: see one, do one or see many, do one? Adv Health Sci Educ. 1999; 4:12343.

10. Dornan T, Littlewood S, Margolis SA, Scherpbier A, Spencer J, Ypinazar V. A BEME systematic review: how can experience in clinical and community settings contribute to early medical education? Med Teach. 2006; 28(1):3-18

11. General Medical Council. Tomorrow's Doctors: recommendations on undergraduate medical education. London: General Medical Council, 2003.

12. Remmen R, Scherpbier A, van der Vleuten C, Denekens J, Derese A, Hermann I, et al. Effectivenes of basic clinical skills training programes: a crosssectional comparison of four medical schools. Med Educ. 2001; 35:121-8.

13. Claramita M, Widyandana. The skills laboratory. Yogyakarta: Fakultas Kedokteran Universitas Gadjah Mada Press, 2008.

14. Prince KJAH, Boshuizen HPA, van der Vleuten C, Scherpbier AJJA. Students opinions about their preparation for clinical practice. Med Educ. 2005; 39:704-12.

15. Widyandana D, Majoor GD, Scherpbier AJJA. Transfer of undergraduates' clinical skills from laboratory to the clinic: students' challenges and their suggestions for improvements. Educ Health (Abingdon), 2010; 23(3):339.

16. Sarikaya O, Civaner M, Kalaca S. The anxieties of medical students related to clinical training. Int J Clin Pract, 2006; 60(11):1414-8.

17. Yuwono A, Widyandana, Hadianto T. Hubungan antara tingkat kesiapan mahasiswa memasuki pendidikan profesi dengan nilai objective structured clinical examination dan indeks prestasi kumulatif. JPKI. 2009: 3(4):152-65.

18. Fraenkel JR, Wallen NE. How to design and evaluate research in education. 8th ed. New York: McGrawHill, 2009. 
19. Driessen E. The self critical doctor: a portofolio to stimulate and assess reflective skills [dissertation]. Maastricth: Maastricth University Press, 2008.

20. Bryman A, Cramer D. Qualitative data analysis with SPSS release 10 for windows, also suitable for SPSS realease 11 , a guide for social scientist. New York: Routledge, 2001.

21. Elo ES, Kyngäs H. The qualitative content analysis process. Adv Nurs J. 2008; 62:107-15.

22. Higgs J, Jones M, Loftus S, Christensen S. Clinical reasoning in the health professions. $3^{\text {rd }}$ ed. Amsterdam: Elsevier (Butterworth Heinemann), 2008.

23. Freidson E. Professionalism reborn: theory, prophecy and policy. Chicago: University of Chicago Press, 1994.

24. Fish D, Coles C. Developing professional judgement in health care: learning through the critical appreciation of practice. Oxford: ButterworthHeinemann, 1998.
25. Higgs J, Burn A, Jones M. Integrating clinical reasoning and evidence-based practice. AACN Clin Issues. 2001;12(4):482-90.

26. Ryle G. The concept of the mind. Chicago: University of Chicago Press, 1949.

27. Sandars J. The use of reflection in medical education: AMEE guide no 44. Med Teach. 2009; 31(8):68595.

28. Jones R, Jenkins F. Managing and leading in allied health professions. Abingdon: Radcliffe Publishing, 2006.

29. Rycroft-Malone J, Seers K, Titchen A, Harvey G, Kitson A, McCormack B. What counts as evidence in evidence-based practise. J Adv Nurs. 2004; 47:8190.

30. Higgs J, Titchen A. Practice knowledge \& expertise in the health professions. Oxford: ButterworthHeinemann, 2001. 